\title{
THE INFLUENCE OF PROPOFOL ON HEPATIC ISCHEMIA/REPERFUSION INJURY IN RATS
}

\author{
YANLI ZHANG ${ }^{1}$, ZHIHUI CHEN ${ }^{2}$, SHUANG SONG ${ }^{3}$, WEIWEI ZHONG ${ }^{1}$, CHUNMEI FENG ${ }^{4}$, \\ HONGLIAN XIA ${ }^{1 *}$
}

${ }^{1}$ Department of Anaesthesiology, Affiliated Hongqi Hospital of Mudanjiang Medical University, Mudanjiang City, 157011, China ${ }^{2}$ Department of Emergency, Affiliated Hongqi Hospital of Mudanjiang Medical University, Mudanjiang City, 157011, China ${ }^{3}$ Department of Ulteasonic, Affiliated Hongqi Hospital of Mudanjiang Medical University, Mudanjiang City, 157011, China ${ }^{4}$ Department of Pathology, Affiliated Hongqi Hospital of Mudanjiang Medical University, Mudanjiang City, 157011, China

*corresponding author: xiahonglianhl00@126.com

Manuscript received: March 2020

\begin{abstract}
This study aimed to evaluate the protective effect of propofol against ultrastructure damage of the rat hepatic tissues in a murine model of hepatic ischemia/reperfusion injury (HIRI), and the underlying mechanism. The treatment with $20 \mathrm{mg} / \mathrm{kg}$ bw/h propofol continuously pumped via the femoral vein upon the moment of reperfusion, in the rats that underwent a HIRI model decreased aspartate aminotransferase (AST) and alanine aminotransferase (ALT) levels, downregulated the expression of c-fos, c-jun and P53, upregulated the expression of Bcl-2 and decreased the apoptosis index of hepatocytes and the pathological injuries significantly compared to the model group. Propofol treatment could relieve HIRI in rats, and its mechanism is associated with the regulation of Bcl-2 expressions and downregulation of c-fos and c-jun, which mitigated the damage to the ultrastructure of hepatic tissues.
\end{abstract}

\section{Rezumat}

Acest studiu a urmărit evaluarea efectului protector al propofolului asupra afectării ultrastructurii țesuturilor hepatice de șobolan într-un model murin de leziune ischemică/reperfuzie (HIRI). Tratamentul cu doze de $20 \mathrm{mg} / \mathrm{kgc} / \mathrm{h}$ propofol administrat continuu prin vena femurală în momentul reperfuziei au scăzut nivelurile de aspartat aminotransferază (AST) și alanin aminotransferază (ALT), au redus expresia c-fos, c-jun și P53, au reglat expresia Bcl-2 şi au scăzut semnificativ indicele de apoptoză al hepatocitelor și leziunilor patologice în comparație cu grupul control. Tratamentul cu propofol ar putea înlătura apariția HIRI la șobolani, iar mecanismul său este asociat cu reglarea expresiilor Bcl-2, c-fos și c-jun, care au atenuat deteriorarea ultrastructurii țesuturilor hepatice.

Keywords: hepatic ischemia/reperfusion injury, propofol, immunohistochemistry, ultrastructure

\section{Introduction}

Hepatic ischemia/reperfusion injury (HIRI) is one of the major challenges in the clinic, which usually occurs alongside post-shock liver failure, liver transplantation, liver injury and liver tumour surgery $[1,2]$. It has been shown that propofol is protective against the ischemia/ reperfusion injury (IRI) of many organs, including heart, brain and liver [3]. Besides its direct effect on the vascular smooth muscles [4], propofol also can dilate peripheral vessels, increasing blood flow, improving circulation and resisting oxidation [5, 6]. Propofol shares a similar chemical structure with vitamin $\mathrm{E}$ and anti-oxidant dibutyl hydroxytoluene (BHT) [7] and can be inactivated by binding to and reacting with the free oxygen radicals. It has been shown that propofol blocks lipid peroxidation and forms a stable, inactive product with the lipid peroxy radicals, thereby eliminating the free oxygen radicals [8, 9]. Because of its good lipid solubility, propofol can easily accumulate on the lipid membrane of the cells, which further promotes the anti-oxidative resistance [10]. Moreover, propofol has an anti-apoptotic effect by regulating the intracellular calcium homeostasis [11]. In the present study, we aimed to investigate the protective effect of propofol against ultrastructure damage of the rat hepatic tissues in a murine model of HIRI, and the underlying mechanism.

\section{Materials and Methods}

Thirty-six healthy Sprague Dawley (SD) rats at 8 - 10 weeks of age and weighing $200 \mathrm{~g}-230 \mathrm{~g}$ were used in the experiment. The animals were kept in separate cages and bred in a clean environment with constant temperature and humidity. They were allowed free access to standard feed and water. The animals have fasted for $12 \mathrm{~h}$ before the experiment, with free access to water. The animal experiment protocol was approved by the ethics committee of Affiliated Hongqi Hospital of Mudanjiang Medical University, China, and the experiment also followed the regulations of the State 
Science and Technology Commission on the management of laboratory animals.

The rats were randomly divided into three groups: a sham operation group (group I), HIRI group (group II) and propofol treatment group (group III).

The treatments administered are described below. Group I: each rat received an intraperitoneal injection of $3 \%$ hydrated chloral $(350 \mathrm{mg} / \mathrm{kg}$ bw) (Guangzhou PythonBio Co., Ltd., China). After anaesthetic induction, the rats were immobilized in a supine position onto a self-made operating table. The skin was conventionally prepared for the abdomen, with routine disinfection and draping procedures. A median incision was made in the abdomen to expose the portal area of the liver fully, and the hepatoduodenal ligament, the portal vein of the left and middle lobes of the liver, hepatic artery and bile duct were separated, without blocking the blood flow. After 30 minutes, an equal volume of normal saline was continuously pumped via the femoral vein for $1 \mathrm{~h}$.

For rats in group II and group III, a model of HIRI was induced. The rats were anaesthetized by intraperitoneal injection of $3 \%$ hydrated chloral $(350 \mathrm{mg} /$ $\mathrm{kg} \mathrm{bw})$. After anaesthetic induction, the rats were immobilized in a supine position onto a self-made operating table. The skin was conventionally prepared for the abdomen, with routine disinfection and draping procedures. A median incision was made in the abdomen to expose the portal area of the liver fully and the hepatoduodenal ligament was carefully isolated. The portal vein supplying the left and middle lobes of the liver, hepatic artery and bile duct was clipped using a non-invasive miniature aorta clamp for 30 minutes. The branches in the right lobe of the liver, papillary process of the liver, and caudate lobe were preserved to prevent congestion in the portal vein and gastrointestinal tract. Induction of liver ischemia was considered successful when the liver texture became soft, and the surface colour turned grey. Reperfusion was considered successful when the liver surface colour restored redness.

The rats in group III received from the moment of reperfusion $20 \mathrm{mg} / \mathrm{kg}$ bw/h propofol (Wuhan Xinxinjiali Bio-Tech Co., Ltd., China) continuously pumped for $1 \mathrm{~h}$ via the femoral vein. The rats in group II received from the moment of reperfusion the same of the normal saline as the rats in the group III.

Sample collection

$3 \mathrm{~mL}$ of blood samples were collected from the inferior vena cava $1 \mathrm{~h}$ after reperfusion and then centrifuged at $4^{\circ} \mathrm{C}$ and $2000 \mathrm{rpm}$ for $10 \mathrm{~min}$. The supernatant was collected and preserved at $-80^{\circ} \mathrm{C}$ prior to the determination of activities of AST and ALT in the serum. After blood sampling, the rats were beheaded under deep anaesthesia using 10\% hydrated chloral ( $350 \mathrm{mg} / \mathrm{kg} \mathrm{bw}$ ) (Guangzhou PythonBio Co., Ltd., China). Tissues of about $2.0 \mathrm{~cm} \times 2.0 \mathrm{~cm} \times 0.3 \mathrm{~cm}$ were immediately harvested from the centre of the middle lobe of the liver. The tissues were fixed in $10 \%$ neutral formalin, dehydrated conventionally, embedded in paraffin and used for detecting protein expressions. From the margin of the left lobe of the liver, tissues of about $1 \mathrm{~mm} \times 1 \mathrm{~mm} \times 3 \mathrm{~mm}$ were immediately harvested and fixed in $4 \%$ glutaraldehyde (Jinan Jibin Chemical Co., Ltd., China) fixing solution at $4^{\circ} \mathrm{C}$. After fixing, the slides were stained with uranyl acetate, and lead citrate (Head (Beijing) Biotechnology Co., Ltd., China) and ultrastructure were observed under an electron microscope (Leica, Germany).

Serological detection

The activities of aspartate aminotransferase (AST) and alanine aminotransferase (ALT) in the serum were determined using an automatic biochemical analyser (Beckman Coulter Inc., USA).

\section{Immunohistochemistry}

For each group, tissue samples were fixed in $10 \%$ formaldehyde and embedded in paraffin. Immunohistochemical staining was performed in strict accordance with the instruction manual of the immunohistochemistry kits (Bcl-2 immunohistochemistry kit, Shanghai Xinyu Biological Technology Co., Ltd., China; c-fos, c-jun immunohistochemistry kit, Shanghai Caiyou Industrial Co., Ltd., China; P53 immunohistochemistry kit, Fuzhou Maixin Biotech. Co., Ltd., China). Briefly, cells positive for Bcl-2 were stained brownish-yellow in the cytoplasm, and those positive for c-fos, c-jun and P53 expressions were stained brownish-yellow in the nuclei. The tissue sections were observed under the microscope (Leica, Germany). Image-Pro ${ }^{\circledR}$ Plus v 6.0 software (Media Cybernetics, USA) was used for the analysis. Five fields of view were randomly selected and the number of positive cells was counted. The percentage of positive cells to total cells was calculated.

Western Blotting

Hepatic tissues were taken and weighed in the precision balance, and $1 \mathrm{~mL}$ of RIPA (Radio Immunoprecipitation Assay) lysis buffer (Shanghai Regal Biotechnology Development Co., Ltd., China) was added into every $50 \mathrm{mg}$ of the tissues. Homogenization was performed on ice. 30 minutes after the lysis, centrifugation was performed at $3000 \times \mathrm{g}$ and $4^{\circ} \mathrm{C}$ for $30 \mathrm{~min}$, and the supernatant was collected. Protein concentrations were determined by using the bicinchoninic acid (BCA) method. The loading sample contained $50 \mu \mathrm{g}$ of the protein and was subjected to sodium dodecyl sulphate polyacrylamide gel electrophoresis (SDS-PAGE) and transferred to the membrane. After the membrane was sealed with 5\% defatted milk powder (Jiangsu Caiwei Biotechnology Co., Ltd., China) for $1 \mathrm{~h}$, the tissues were hybridized with primary antibodies against cfos (1:3000, Shanghai Ruichu Biotechnology Co., Ltd., China), c-jun (1:1000, Shanghai Ruichu Biotechnology Co., Ltd., China), Bcl-2 (1:2000, Abgent, USA) and P53 (1:1000, Desen Biological Reagent Co., Ltd., China) and the corresponding secondary antibodies 
FARMACIA, 2020, Vol. 68, 4

(goat anti-rabbit IgG-HRP [1:5000, Real-Times Biotechnology Co., Ltd., China]). The membrane was washed and treated with the electrochemiluminescence substrate (Shanghai Yanhui Biotechnology Co., Ltd., China). The membrane was then exposed to the Kodak chemofluorescence detector (DL Naturegene Life Sciences, Inc. USA) to visualize the target proteins, and photos were taken. Quantity One software was used for quantitative analysis of the target bands. The grayscale ratio of the target band to the $\beta$-actin band was used to represent the relative expression of the target proteins.

TUNEL assay

TUNEL assay was performed to determine liver cell apoptosis. Apoptotic cells were those with nuclei stained brownish yellow under the microscope. For each case, 5 fields of view were randomly selected from the slice, and the average number of apoptotic cells per 100 cells was determined. Its percentage was expressed as AI (apoptotic index).

Ultrastructure observation of hepatic tissues under the electron microscope

From the margin of the left lobe of the liver, tissues of about $1 \mathrm{~mm} \times 1 \mathrm{~mm} \times 3 \mathrm{~mm}$ were immediately harvested and fixed in $2.5 \%$ glutaraldehyde fixing solution at $4^{\circ} \mathrm{C}$ for $2 \mathrm{~h}$. The tissue was washed with $1 / 15 \mathrm{M}$ PBS (phosphate buffered saline) buffer at $4^{\circ} \mathrm{C}$ in the fridge. Then the tissues were fixed in $1 \%$ osmium tetroxide $\left(\mathrm{O}_{\mathrm{S}} \mathrm{O}_{4}\right)$ (Shanghai Yanjin Biotechnology Co., Ltd., China) at $4^{\circ} \mathrm{C}$ in the fridge for $1-2 \mathrm{~h}$. After that, the tissues were washed with $1 / 15 \mathrm{M}$ PBS buffer twice at $4^{\circ} \mathrm{C}$ in the fridge, $20 \mathrm{~min}$ each time. The tissues were dehydrated with gradient concentrations of acetone. In the incubator at $37^{\circ} \mathrm{C}$, the tissues were embedded in pure acetone (Wuhan Sanheshun Chemical Co., Ltd., China) mixed with embedding agent (Shanghai Huake Experimental Equipment Co., Ltd., China) in a 1:1 proportion for $1 \mathrm{~h}$. This was followed by soaking in pure acetone mixed with embedding agent in a $1: 3$ proportion for over $3 \mathrm{~h}$. Finally, the tissues were soaked in pure embedding agent for over $5 \mathrm{~h}$ or overnight. After soaking, the tissue samples were subpackaged into $2 \mathrm{~mL}$ EP tubes and embedded, which were then heated at $70^{\circ} \mathrm{C}$ overnight. The samples were placed in the incubator at $37^{\circ} \mathrm{C}$ for $12 \mathrm{~h}$, followed by baking in the oven at $60^{\circ} \mathrm{C}$ for $36-48 \mathrm{~h}$. The samples were cut sliced into $50 \mathrm{~nm}$ slides. After double staining with uranyl acetate and lead citrate, changes in the organelles of the hepatic tissues were observed under the electron microscope (Leica, Germany), including nuclei, chromatin, mitochondria, glycogen granules and rough endoplasmic reticulum.

Statistical analysis

SPSS 19.0 software (IBM, USA) was used for statistical analysis. All measurements had a normal distribution and were expressed as mean \pm standard deviation. Oneway ANOVA was performed for intergroup comparison, and a value of $\mathrm{p}<0.05$ indicated a significant difference.

\section{Results and Discussion}

Comparison of activities of aspartate aminotransferase (AST) and alanine aminotransferase (ALT) in the serum The AST and ALT levels significantly increased in group II and III compared to group I (Table I). Propofol treatment significantly decreased AST and ALT levels compared to group II (Table I).

Table I

Comparison of activities of AST and ALT in the serum between the three groups (U/L)

\begin{tabular}{lccc}
\hline Group & Group I & Group II & Group III \\
\hline AST & $82.19 .4 \pm 10.27$ & $172.18 \pm 20.23^{*}$ & $139.24 \pm 18.47 * \#$ \\
ALT & $69.28 \pm 7.9$ & $111.29 \pm 18.37^{*}$ & $87.25 \pm 13.26 * \#$ \\
\hline
\end{tabular}

* $\mathrm{p}<0.05$, compared to group I; \#p < 0.05, compared to group II

A

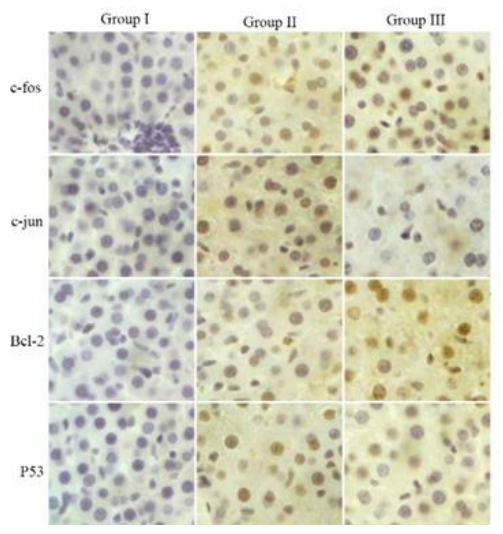

B

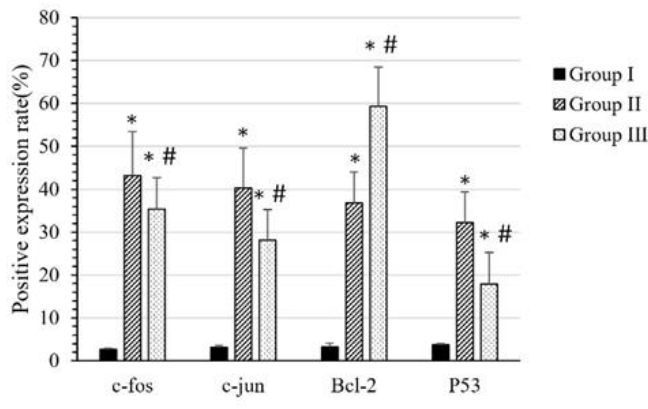

Figure 1.

Positive expressions rates of c-fos, c-jun, Bcl-2 and P53 in hepatic tissues

(A: Immunohistochemistry results; B: Positive expression statistics. $* \mathrm{p}<0.05$, compared to group I; \#p < 0.05, compared to group II) 
Table II

Positive expressions of c-fos, c-jun, Bcl-2 and P53 (\%)

\begin{tabular}{lccc}
\hline Group & Group I & Group II & Group III \\
\hline c-fos & $2.63 \pm 0.29$ & $43.19 \pm 10.28^{*}$ & $35.33 \pm 7.39^{* \#}$ \\
c-jun & $3.17 \pm 0.42$ & $40.28 \pm 9.33^{*}$ & $28.13 \pm 7.18^{* \#}$ \\
Bcl-2 & $3.21 \pm 0.84$ & $36.76 \pm 7.23^{*}$ & $59.37 \pm 9.11^{* \#}$ \\
P53 & $3.71 \pm 0.28$ & $32.19 \pm 7.12^{*}$ & $17.88 \pm 7.37^{* \#}$ \\
\hline
\end{tabular}

*p $<0.05$, compared to group I; \#p $<0.05$, compared to group II

Comparison of positive expression rates of $c$-fos, c-jun, Bcl-2 and P53 in the hepatic tissues

The expressions of c-fos, c-jun, Bcl-2 and P53 were upregulated in group II and group III compared to group I. Propofol treatment downregulated the expressions of c-fos, c-jun and P53 and upregulated the expression of Bcl-2 compared to group II (Figure 1 and Table II).
Protein expressions detected by Western Blot

The protein expression c-fos, c-jun and P53 and Bcl-2 significantly increased in group II and group III compared to group I. Propofol treatment significantly decreased the protein expression of c-fos, c-jun and P53 and significantly increased the protein expression of Bcl-2 compared to group II (Figure 2).
A

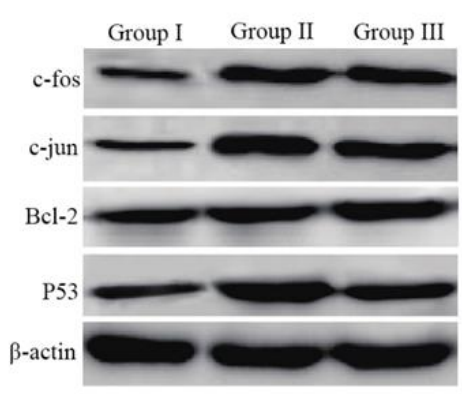

B

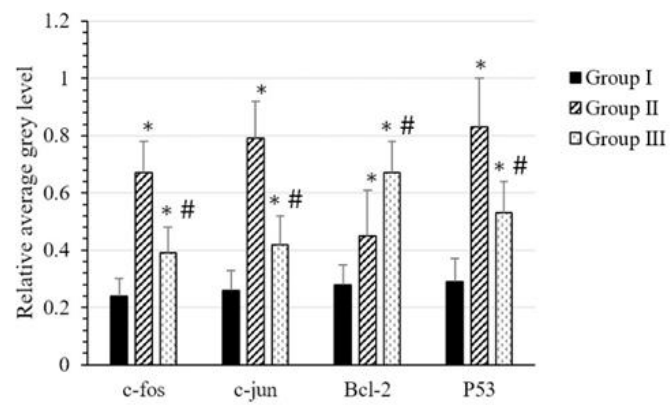

Figure 2.

Western Blot results

(A: Western Blot diagram; B: Relative grayscale of the proteins. $* \mathrm{p}<0.05$, compared to group I; \#p $<0.05$, compared to group II)

Table III Changes in AI of hepatocytes

\begin{tabular}{cccc}
\hline Group & Group I & Group II & Group III \\
\hline AI & $3.18 \pm 2.19$ & $26.27 \pm 4.11 *$ & $16.28 \pm 3.02 * \#$ \\
\hline
\end{tabular}

${ }^{*} \mathrm{p}<0.05$, compared to group I; \#p $<0.05$, compared to group II

Changes in AI of hepatocytes

TUNEL assay showed that AI of hepatocytes in groups II and III increased significantly compared to group I. Propofol treatment significantly decreased the AI in group III compared to group II (Table III).

Ultrastructure observation of hepatic tissues under the electron microscope

No apparent abnormalities were found in the structure of rat hepatocytes in group I. The nucleoli were plump with the smooth and intact nuclear membrane. The nuclear pores were of normal morphology with a diffuse distribution of chromatin. Mitochondria were quasi-elliptical with clearly visible cristae. The glycogen granules were extensively distributed. The rough endoplasmic reticula were of regular morphology and neat arrangement. The intercellular bridges and connections were tight and abundant. The microvilli in the bile capillaries presented a cubic shape with extensive distribution.
In group II, the nucleoli were of abnormal morphology, with dents in the nuclear membrane and altered morphology of nuclear pores. The chromatic aggregated to form clusters and accumulated along the margins, instead of at one end of the cells. There was severe mitochondrial swelling with the massive disappearance of cristae. The number of glycogen granules decreased dramatically. The rough endoplasmic reticula showed dilation and rupture to different degrees. The intracellular connections were obscure, and the microvilli in the bile capillaries were elliptical, with a reduction in the amount. There were evident vacuolated changes in the cells.

In group III, the nuclear pattern presented with mild atypical changes, with alleviated karyopyknosis and mild dents in the nuclear membrane. The chromatin was uniformly distributed, but with localization along the margins. The cytoplasm contained a large number of mitochondria with moderately good structure. The number of glycogen granules was increased compared 
FARMACIA, 2020, Vol. 68, 4

to group II. The rough endoplasmic reticula showed lamellar arrangement, with insignificant swelling. The intracellular connections were moderately good, and there were a large number of microvilli in the bile capillaries with good morphology (Figure 3).
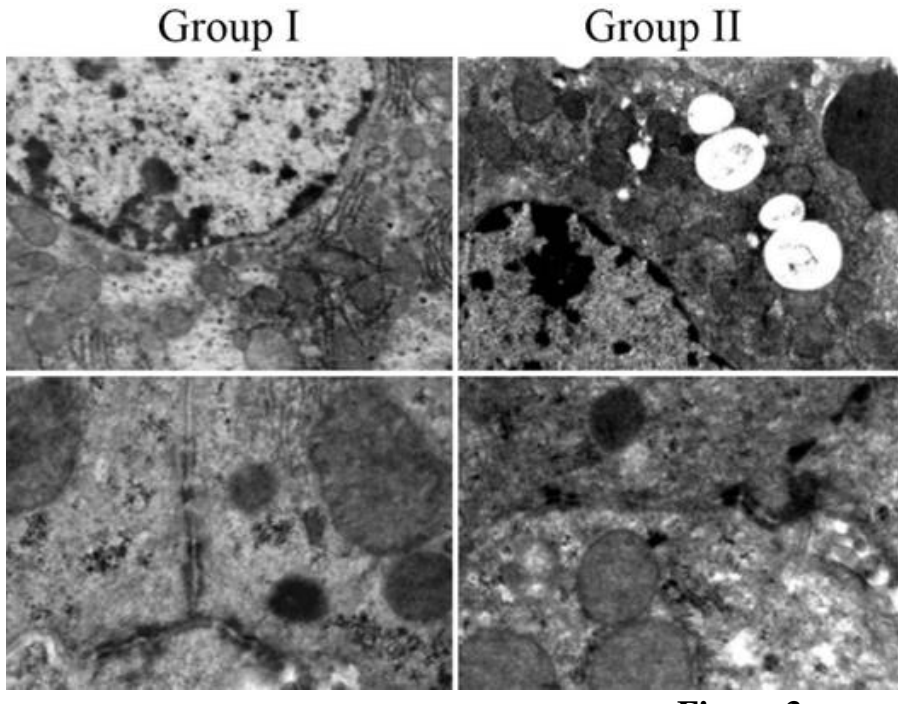

Figure 3.

Ultrastructure observations of hepatic tissues in each group
The liver is very sensitive to ischemia and hypoxia and plays a role in regulating the anti-viral and antiinfection immune responses [12]. AST and ALT are direct serum enzymatic indicators of liver function damage [13]. Our results indicated that compared to the normal control group (group I), serum AST and ALT levels increased significantly in group II, indicating that ischemia/reperfusion caused severe damage to rat liver function and that the HIRI model was successfully obtained. Propofol post-treatment alleviated the ischemiareperfusion injury (IRI) in rat liver translated by a significant decrease in serum AST and ALT levels compared to group II.

c-fos and c-jun are immediate genes (IEGs), and their activation is involved in the regulation of the signalling and responses of the cells and tissues to the injury stimuli. Therefore, they are generally considered as one of the primary mechanisms involved in intracellular and extracellular signal transduction in ischemiareperfusion injury (IRI) [14]. Some studies [15, 16] showed that the continuous overexpression of the cfox and c-jun genes could be used as a marker for the activation of cell apoptosis. In other studies [14, 17], c-fos and c-jun were upregulated after ischemia/reperfusion. Our experiment showed that compared to group II, c-fos and c-jun were downregulated in the hepatic tissues in group III treated with propofol. The mechanism has been previously reported to be associated with the induction of c-fos and c-jun expressions by the nitric oxide, cytokines and free oxygen radicals $[17,18]$. Ischemia/reperfusion can cause a massive generation of free oxygen radicals. Propofol, sharing a similar chemical structure with the anti-oxidant vitamin E and BHT, also contains a phenol ring that can clear the free radicals. In this study, propofol treatment downregulate the expression of c-fos and c-jun in the hepatocytes, thereby reducing cell apoptosis.

Apoptosis is the genetically controlled programmed cell death that is essential for the maintenance of cellular homeostasis and involves the activation, expression and regulation of a series of genes [19]. Due to increased production of reactive oxygen species and calcium overload upon ischemia/reperfusion as well as continued low $\mathrm{pH}$ value, the permeability of the mitochondrial inner membrane is altered, and the transmembrane potential and energy synthesis are lowered, eventually leading to cell apoptosis [20, 21]. Bcl-2 is mainly localized to the mitochondrial outer membrane and has an antagonizing effect against the pro-apoptotic proteins [22]. Tumour inhibitory factor P53 is an upstream regulatory gene of Bcl-2. By binding to Bcl-2, P53 can downregulate its expression, promoting cell apoptosis [23]. We found that the number of cells positive for Bcl-2 and P53 and AI increased during HIRI in group II. Propofol treatment leads to an increase of cells positive for Bcl-2 associated with a decrease of cells positive for P53 and AI compared to group II. This demonstrated the role of apoptosis in HIRI. Moreover, the level of apoptosis in the propofol treatment group was considerably lower than that of the group without pretreatment, suggesting that propofol could effectively inhibit HIRI-induced cell apoptosis. HIRI is a complex pathophysiological process involving multiple mechanisms, including mitochondrial dysregulation [24]. It has been shown that a vicious cycle can be initiated in the mitochondria. The reactive oxygen species (ROS) associated with the damaged 
mitochondria interfere with electron transport and damage the liposomes. These changes further inhibit ATP synthesis and aggravate the disruption of the respiratory chain and ROS generation [25]. Oxidative injury of the mitochondrial membrane impairs the structural and functional integrity of the mitochondrial membrane, leading to alteration of cellular functions [26]. Another study [27] has shown that HIRI can decrease the activity of the mitochondrial $\mathrm{Na}^{+} / \mathrm{K}^{+}$ATPase and cause mitochondrial injury. In IRI, another important role performed by the mitochondria is regulating the programmed cell death (PCD), or apoptosis. Glycogen is mainly found in the cytoplasm of hepatocytes and muscle cells and acts as the glucose reserve. When the liver is ischemic, glycogen can be decomposed into glucose to supply energy to the tissues, thereby alleviating the severity of HIRI [28]. In a clinical study [29] there was shown that glycogen reserve has an excellent protective effect in HIRI. In the present study, the nuclear pattern of the hepatocytes was abnormal under the electron microscope in group II, with chromatin aggregating along the margin and severe mitochondrial swelling. The number of cristae and glycogen granules decreased significantly, indicating apparent IRI to the rat hepatocytes. In group III, the hepatocytes were less severely damaged, the nuclei were of a basically normal structure, and the chromatin was more uniformly distributed. Besides, the mitochondrial swelling was less significant and the number of glycogen granules increased considerably compared to group II. This is probably associated with the fact that propofol has a high lipid solubility and can easily enter the cell membrane, thereby inhibiting lipid peroxidation. As a result, cell apoptosis can be inhibited by reducing ROS generation, which further mitigates HIRI in rats.

\section{Conclusions}

Propofol treatment could alleviate HIRI in rats. The mechanism involved is associated with the regulation of Bcl-2 expressions and downregulation of c-fos and c-jun in the hepatic tissues, which mitigated the damage to the ultrastructure of hepatic tissues.

\section{Acknowledgement}

This work was supported Basic scientific research cost scientific research project of University in Heilongjiang Province (2017-KYYWF-0642).

\section{Conflict of interest}

The authors declare no conflict of interest.

\section{References}

1. Messiha BA, Abo-Youssef AM, Protective effects of fish oil, allopurinol, and verapamil on hepatic ischemiareperfusion injury in rats. J Nat Sci Biol Med., 2015; 6(2): 351-355.
2. Ozturk H, Cetinkaya A, Erdogan Duzcu S, Yis OM, Ozturk H, Carvacrol reduces the severity of intestinal mucosal damage caused by intestinal ischemia reperfusion in rats. Farmacia, 2019; 67(5): 892-898.

3. Katwal G, Baral D, Fan X, Weiyang H, Zhang X, Ling L, Xiong Y, Ye Q, Wang Y, SIRT3 a Major Player in Attenuation of Hepatic Ischemia-Reperfusion Injury by Reducing ROS via Its Downstream Mediators: SOD2, CYP-D, and HIF-1 $\alpha$. Oxid Med Cell Longev., 2018; 2018: 2976957.

4. Tao KM, Yang LQ, Liu YT, Tao Y, Song JC, Wu FX, $\mathrm{Yu}$ WF, Volatile anesthetics might be more beneficial than propofol for postoperative liver function in cirrhotic patients receiving hepatectomy. Med Hypotheses, 2010; 75(6): 555-557.

5. Ranjbar A, Sharifzadeh M, Karimi J, Tavilani H, Baeeri M, Heidary Shayesteh T, Abdollahi M, Propofol Attenuates Toxic Oxidative Stress by CCl4 in Liver Mitochondria and Blood in Rat. Iran J Pharm Res., 2014; 13(1): 253-262.

6. Özkan D, Akkaya T, Yalcindag A, Hanci T, Gönen E, Gümüs H, Delibas N, Propofol sedation in total knee replacement: effects on oxidative stress and ischemia-reperfusion damage. Anaesthesist, 2013; 62(7): 537-542.

7. Acquaviva R, Campisi A, Murabito P, Raciti G, Avola R, Mangiameli S, Musumeci I, Barcellona ML, Vanella A, Li Volti G, Propofol attenuates peroxynitritemediated DNA damage and apoptosis in cultured astrocytes: an alternative protective mechanism. Anesthesiology, 2004; 101(6): 1363-1371.

8. Yen HC, Chen TW, Yang TC, Wei HJ, Hsu JC, Lin CL, Levels of F2-isoprostanes, F4-neuroprostanes, and total nitrate/nitrite in plasma and cerebrospinal fluid of patients with traumatic brain injury. Free Radic Res., 2015; 49(12): 1419-1430.

9. Zhou X, Lu D, Li WD, Chen XH, Yang XY, Chen X, Zhou ZB, Ye JH, Feng X, Sevoflurane Affects Oxidative Stress and Alters Apoptosis Status in Children and Cultured Neural Stem Cells. Neurotox Res., 2018; 33(4): 790-800.

10. Sun X, Gu J, Chi M, Li M, Lei S, Wang G, Activation of PI3K-Akt through taurine is critical for propofol to protect rat cardiomyocytes from doxorubicin-induced toxicity. Can J Physiol Pharmacol., 2014; 92(2): 155161.

11. Wang L, Ko KW, Lucchinetti E, Zhang L, Troxler H, Hersberger M, Omar MA, Posse de Chaves EI, Lopaschuk GD, Clanachan AS, Zaugg M, Metabolic profiling of hearts exposed to sevoflurane and propofol reveals distinct regulation of fatty acid and glucose oxidation: CD36 and pyruvate dehydrogenase as key regulators in anesthetic-induced fuel shift. Anesthesiology, 2010; 113(3): 541-551.

12. Ju C, Colgan SP, Eltzschig HK, Hypoxia-inducible factors as molecular targets for liver diseases. $\mathrm{J} \mathrm{Mol}$ Med (Berl.), 2016; 94(6): 613-627.

13. Frățilă $\mathrm{O}$, Mihele AI, Hodisan-Pap EF, Hocopan SC, Brata R, Iliaş T, Comparative hepatoprotective efficacy of silymarin-phyllanthus-choline combination versus silymarin alone in liver diseases with different destruction and inflammation stages. Farmacia, 2020; 68(2): 299-306. 
14. Santos MM, Tannuri AC, Coelho MC, Gonçalves Jde O, Serafini S, Silva LF, Tannuri U, Immediate expression of c-fos and c-jun mRNA in a model of intestinal autotransplantation and ischemia-reperfusion in situ. Clinics (Sao Paulo), 2015; 70(5): 373-379.

15. Shima $Y$, Tajiri $T$, Taguchi $T$, Suita $S$, Increased expression of c-fos and c-jun in the rat small intestinal epithelium after ischemia-reperfusion injury: a possible correlation with the proliferation or apoptosis of intestinal epithelial cells. J Pediatr Surg., 2006; 41(4): 830-836.

16. Itoh H, Yagi M, Hasebe K, Fushida S, Tani T, Hashimoto T, Shimizu K, Miwa K, Regeneration of small intestinal mucosa after acute ischemiareperfusion injury. Dig Dis Sci., 2002; 47(12): 2704-2710

17. Xiao JS, Cai FG, Niu Y, Zhang Y, Xu XL, Ye QF, Preconditioning effects on expression of proto-oncogenes c-fos and c-jun after hepatic ischemia/reperfusion in rats. Hepatobil Pancreat Dis Int., 2005; 4(2): 197-202.

18. Dai Y, Sun X, Chen Q, Differential induction of c-Fos and c-Jun in the lateral geniculate nucleus of rats following unilateral optic nerve injury with contralateral retinal blockade. Exp Brain Res., 2009; 193(1): 9-18.

19. Deng YJ, Tan N, Zeng HK, Fu YH, Dong XL, Effects of BNP preconditioning on myocardial cell apoptosis and expressions of bcl-2 and Bax during myocardial ischemia-reperfusion injury in rats. Zhonghua $\mathrm{Yi}$ Xue Za Zhi, 2010; 90(48): 3431-3434.

20. Lin M, Li L, Li L, Pokhrel G, Qi G, Rong R, Zhu T, The protective effect of baicalin against renal ischemiareperfusion injury through inhibition of inflammation and apoptosis. BMC Complement Altern Med 2014; 14: 19: 1-9.

21. Dai S, Xu Q, Liu S, Yu B, Liu J, Tang J, Role of autophagy and its signaling pathways in ischemia/ reperfusion injury. Am J Transl Res., 2017; 9(10): 4470-4480.

22. Liu F, Jiang YJ, Zhao HJ, Yao LQ, Chen LD, Electroacupuncture ameliorates cognitive impairment and regulates the expression of apoptosis-related genes
$\mathrm{Bcl}-2$ and $\mathrm{Bax}$ in rats with cerebral ischaemia-reperfusion injury. Acupunct Med., 2015; 33(6): 478-484.

23. EI-Emshaty HM, Saad EA, Toson EA, Abdel Malak CA, Gadelhak NA. Apoptosis and cell proliferation: correlation with BCL-2 and P53 oncoprotein expression in human hepatocellular carcinoma. Hepatogastroenterology, 2014; 61(133): 1393-1401.

24. Cherkashina DV, Sosimchik IA, Semenchenko OA, Volina VV, Petrenko AY, Mitochondria-targeted plastoquinone derivative SkQ decreases ischemiareperfusion injury during liver hypothermic storage for transplantation. Biochemistry (Mosc.), 2011; 76(9): 1022-1029.

25. Sun CK, Zhang XY, Sheard PW, Mabuchi A, Wheatley $\mathrm{AM}$, Change in mitochondrial membrane potential is the key mechanism in early warm hepatic ischemiareperfusion injury. Microvasc Res., 2005; 70(1-2): 102-110.

26. Kuo KK, Wu BN, Chiu EY, Tseng CJ, Yeh JL, Liu $\mathrm{CP}$, Chai CY, Chen IJ, NO donor KMUP-1 improves hepatic ischemia-reperfusion and hypoxic cell injury by inhibiting oxidative stress and pro-inflammatory signaling. Int J Immunopathol Pharmacol., 2013; 26(1): 93-106.

27. Lin S, Liu K, Wu W, Chen C, Wang Z, Zhang X, Study on Pretreatment of FPS-1 in Rats with Hepatic Ischemia-Reperfusion Injury. Am J Chin Med., 2009; 37(2): 323-337.

28. Zhao G, Ma H, Shen X, Xu GF, Zhu YL, Chen B, Tie R, Qu P, Lv Y, Zhang H, Yu J, Role of glycogen synthase kinase $3 \beta$ in protective effect of propofol against hepatic ischemia-reperfusion injury. J Surg Res., 2013; 185(1): 388-398.

29. Kim HJ, Joe Y, Kong JS, Jeong SO, Cho GJ, Ryter SW, Chung HT, Carbon monoxide protects against hepatic ischemia/reperfusion injury via ROS-dependent Akt signaling and inhibition of glycogen synthase kinase 33. Oxid Med Cell Longev., 2013; 2013: 306421: 1-11. 